\title{
Number of repetitions for evaluating technological traits in cotton genotypes
}

\author{
L.P. Carvalho ${ }^{1}$, F.J.C. Farias ${ }^{1}$, C.L. Morello ${ }^{1}$, J.I.S. Rodrigues ${ }^{1}$ and \\ P.E. Teodoro ${ }^{2}$
}

${ }^{1}$ Centro Nacional de Pesquisa de Algodão, Embrapa Algodão, Campina Grande, PB, Brasil

${ }^{2}$ Departamento de Biologia Geral, Universidade Federal de Viçosa, Viçosa, MG, Brasil

Corresponding author: P.E. Teodoro

E-mail: eduteodoro@hotmail.com

Genet. Mol. Res. 15 (3): gmr. 15038557

Received February 15, 2016

Accepted April 11, 2016

Published August 18, 2016

DOI http://dx.doi.org/10.4238/gmr.15038557

Copyright $(\mathcal{C} 2016$ The Authors. This is an open-access article distributed under the terms of the Creative Commons Attribution ShareAlike (CC BY-SA) 4.0 License.

\begin{abstract}
With the changes in spinning technology, technological cotton traits, such as fiber length, fiber uniformity, fiber strength, fineness, fiber maturity, percentage of fibers, and short fiber index, are of great importance for selecting cotton genotypes. However, for accurate discrimination of genotypes, it is important that these traits are evaluated with the best possible accuracy. The aim of this study was to determine the number of measurements (repetitions) needed to accurately assess technological traits of cotton genotypes. Seven experiments were conducted in four Brazilian States (Ceará, Rio Grande do Norte, Goiás, and Mato Grosso do Sul). We used nine brown and two white colored fiber lines in a randomized block design with four replications. After verifying the assumptions of residual normality and homogeneity of variances, analysis of variance was performed to estimate the repeatability coefficient and calculating the number of
\end{abstract}


repetitions. Trials with four replications were found to be sufficient to identify superior cotton genotypes for all measured traits except short fiber index with a selective accuracy $>90 \%$ and at least $81 \%$ accuracy in predicting their actual value. These results allow more accurate and reliable results in future researches with evaluating technological traits in cotton genotypes.

Key words: Gossypium hirsutum L. r. latifolium Hutch.; Repeatability; Experimental planning

\section{INTRODUCTION}

Upland cotton (Gossypium hirsutum L. r. latifolium Hutch.) is one of the main economically important crops in Brazil (Farias et al., 2016). However, to become competitive in the global market, there is a need to identify genotypes with higher quality fiber. This is because the industry requires greater strength during spinning and bundling, and a decrease in the content of short fibers, greater uniformity of length, and amount of mature fibers are also desirable. All these traits are needed to increase the processing speed in the textile industry (Carvalho et al., 2015a,b).

To this end, trials with cotton genotypes assess common technological properties such as fiber length, fiber uniformity, fiber strength, fineness, fiber maturity percentage, and short fiber content (Carvalho et al., 2015c). The correct discrimination of genotypes is important in these trials so that the traits are evaluated accurately. Thus, to achieve the desired accuracy, it is important to properly dimension the trial plots' size and shape, the sample size, and the number of repetitions for each trait of interest (Torres et al., 2015).

Dimensioning the number of repetitions can be performed from data of genotype trials based on repeatability coefficient estimates obtained from analyses of variance (Cruz, 2006). In this scenario, the use of data of trial cultivar competition allows for estimation of the number of repetitions for a certain crop trait, thus enabling the optimization of human and financial resources (Torres et al., 2015).

Based on the coefficient of repeatability, scaling of the number of repetitions has been performed to evaluate agronomic traits of common bean (Cargnelutti Filho and Ribeiro, 2010), soybean (Cargnelutti Filho and Gonçalves, 2011), and maize (Cargnelutti Filho and Guadagnin, 2011). These studies generally revealed variability among traits in the number of repetitions required to obtain a given accuracy. However, the use of repeatability analysis for estimating the number of repetitions of technological cotton traits has been poorly studied. Thus, the aim of this study was to determine the number of measurements (repetitions) required for assessing the traits fiber length, fiber uniformity, fiber strength, fineness, fiber maturity, percentage of fibers, and fiber index of cotton genotypes.

\section{MATERIAL AND METHODS}

Seven trials were conducted in the States of Ceará (CE), Rio Grande do Norte (RN), Goiás (GO), and Mato Grosso do Sul (MS). Two trials were conducted in Barbalha-CE, in 2010 and 2011, using crops grown in the dry season with furrow irrigation over the crop cycle. In addition, two trials were conducted in Apodi-RN, in the same years, using crops

Genetics and Molecular Research 15 (3): gmr.15038557 
grown in the rainy season, but with three $15-\mathrm{mm}$ complementary irrigations, due to a dry period that occurred in the region. Finally, one trial was performed in Ipanguassú-RN in 2011, with sprinkler irrigation during the whole crop cycle, one trial was performed in Itaquiraí-MS in 2011, and another was performed in Santa Helena-GO in 2011. The last two trials were performed without irrigation.

Nine brown and two white colored fiber lines were used (BRS Rubi, a cultivar yielding brown fiber and BRS Aroeira, yielding white fiber). The trials were conducted in a randomized block design with four replications. The number of treatments and blocks used in this study is similar to previous studies that have aimed to scale the number of repetitions necessary to evaluate important agronomic traits (Cargnelutti Filho and Ribeiro, 2010; Cargnelutti Filho and Gonçalves, 2011; Cargnelutti Filho and Guadagnin, 2011). Each plot consisted of two 5.0-m lines spaced $1.0 \mathrm{~m}$ apart. The traits evaluated were fiber length $(\mathrm{mm})$, fiber uniformity $(\%)$, fiber strength (gf/tex), fineness (micronaire), fiber maturity (\%), percentage of fibers (\%), and short fiber index (\%). At harvest, 20 bolls from each sample unit were taken for the determination of these fiber traits, which was performed in a high volume instrument, an electronic device currently used for measuring fiber traits. The sample size used in this study $(\mathrm{N}=20)$ is the same as that used in other experiments conducted with upland cotton (Carvalho et al., 2015a,b,c).

In each of the seven trials, data from traits evaluated followed a statistical model of a randomized block design given by:

$$
Y_{i j}=\mu+\tau_{i}+\beta_{j}+\varepsilon_{i j}
$$

(Equation 1)

where $Y_{i j}$ is the observed value of the response variable in plot $i j, \mu$ is the overall mean, $\tau_{i}$ is the genotype effect $(i=1,2, \ldots, 11), \beta_{j}$ is the block effect $(j=1,2,3,4)$, and $\varepsilon_{i j}$ is the effect of the supposed standard experimental error that is randomly distributed with mean 0 and common variance $\sigma^{2}$ (Storck et al., 2011). Lilliefors, Bartlett, and Tukey tests were carried out to verify the compliance of the assumptions of residual normality, homogeneity of variance, and additivity of the mathematical model, respectively. Based on the results of analysis of variance, we obtained estimates of mean square of the block $\left(\mathrm{MS}_{\mathrm{B}}\right)$, mean square of the genotype $\left(\mathrm{MS}_{\mathrm{G}}\right)$, mean square of the error $\left(\mathrm{MS}_{\mathrm{E}}\right)$, and the F-test value for the genotype by

$$
\mathrm{Fc}=\mathrm{MS}_{G} \mathrm{MS}_{\mathrm{E}}
$$

(Equation 2)

Subsequently, the selective accuracy (SA) was estimated (Resende and Duarte, 2007) using the expression

$$
S A=(1-(1 / F))^{0.5}
$$

Finally, based on the obtained SA, the experimental accuracy was evaluated according to the class limits established by Resende and Duarte (2007).

Assessments were considered in each block as measurements within the same individual (genotype) and the repeatability coefficient (r) was estimated for each trait and trial by analysis of variance. In this study, $r$ is the intraclass correlation coefficient for genotypes and is estimated by the expression:

Genetics and Molecular Research 15 (3): gmr.15038557 


$$
\mathrm{r}=\left[\left(\mathrm{MS}_{\mathrm{G}}-\mathrm{MS}_{\mathrm{E}}\right) / \mathrm{J}\right] /\left[\left(\mathrm{MS}_{\mathrm{G}}-\mathrm{MS}_{\mathrm{E}}\right) / \mathrm{J}+\mathrm{MS}_{\mathrm{E}}\right] \quad \text { (Equation 4) }
$$

where $J$ is the number of measurements or repetitions (Cruz and Regazzi, 1997; Cruz, 2006).

The $\mathrm{J}$ needed to predict the actual value of individuals (genotypes) based on the preset $(0.80$ and 0.85$)$ genotypic determination coefficients $\left(R^{2}\right)$ was calculated by the following expression (Cruz and Regazzi, 1997):

$$
\mathrm{J}=\left[\mathrm{R}^{2}(1-\mathrm{r})\right] /\left[\left(1-\mathrm{R}^{2}\right) \mathrm{r}\right]
$$

$\mathrm{R}^{2}$, which represents the certainty of prediction of the real value of the selected genotypes, based on J measurements, was obtained by the expression:

$$
\mathrm{R}^{2}=[\mathrm{Jr}] /[1+\mathrm{r}(\mathrm{J}-1)]
$$

where $J$ is the number of measurements ( $\mathrm{J}=4$ blocks, in this study) and $r$ is the repeatability coefficient, as above (Cruz, 2006). The statistical analyses were all performed using the GENES software (Cruz, 2013) and Microsoft Office Excel.

\section{RESULTS AND DISCUSSION}

In the 49 cases analyzed (seven traits $\mathrm{x}$ seven trials), we found that the errors were normally distributed and the mathematical model was additive ( $P>0.05$; Table 1$)$. In 46 cases (94\%), we observed that the residual variances were homogeneous $(\mathrm{P}>0.05)$. Hence, the high rate of non-violation of the assumptions residual normality, homogeneity of variance, and additivity of the mathematical model suggest that the F-test is suitable for determining the sources of variation (block and genotype) of analysis of variance (Storck et al., 2011). Among the 49 cases, the F-test revealed a significant block effect $(\mathrm{P} \leq 0.05)$ in only three cases $(6 \%)$, which indicates that the blocks were homogeneous and that the completely randomized design was appropriate.

The means fiber length, fiber uniformity, fiber strength, fineness, fiber maturity, percentage of fibers, and short fiber index (Table 1) were similar to means previously obtained in other trials with cotton genotypes (Freitas et al., 2007; Araújo et al., 2013; Jerônimo et al., 2014; Carvalho et al., 2015a,b). This suggests suitability of this database for the proposed study, because it represents actual situations of field trials with cotton genotypes.

Regarding fiber length, fiber uniformity, fiber strength, fineness, fiber maturity, and percentage of fibers, there was a significant genotype effect $(P \leq 0.05)$ in the seven tests. This suggests that it is possible to identify superior genotypes based on the genetic variability (Table 1). As for the short fiber index, we found significant genotype effects in all trials except for trials 2 and 4. Hence, the discrimination of genotypes based on this trait, using the F-test, may not be due to lack of genetic variability, but is more likely to be due to lower experimental accuracy (Resende and Duarte, 2007). In the 47 cases (96\%) in which we found a significant genotype effect, the average SA, r, and $\mathrm{R}^{2}$, based on four repetitions, were $0.93,0.66$, and $86.78 \%$, respectively. In contrast, for trials 2 and 4 , for which we did not detect significant genotype effects for short fiber index, the means of SA, r, and $\mathrm{R}^{2}$ were $0.70,0.31$, and $60.35 \%$, respectively. This reinforces the hypothesis that this lack of differences between genotypes is associated with lower experimental accuracy.

Genetics and Molecular Research 15 (3): gmr.15038557 
Table 1. Summary of analysis of variance, mean, selective accuracy (SA), and P values from the normality (Lilliefors), homogeneity of variance (Bartlett), and additivity (Tukey) tests for the seven cotton genotype traits, assessed in seven trials.

\begin{tabular}{|l|l|l|l|l|l|l|l|l|}
\hline Sources of variation & d.f. & Trial 1 & Trial 2 & Trial 3 & Trial 4 & Trial 5 & Trial 6 & Trial 7 \\
\hline
\end{tabular}

\begin{tabular}{|c|c|c|c|c|c|c|c|c|}
\hline \multicolumn{9}{|c|}{ Fiber length (mm) } \\
\hline Block & 3 & $0.50^{\mathrm{ns}}$ & $1.62^{\mathrm{ns}}$ & $0.05^{\mathrm{ns}}$ & $0.73^{\text {ns }}$ & $0.12^{\mathrm{ns}}$ & $0.17^{\mathrm{ns}}$ & $0.52^{\mathrm{ns}}$ \\
\hline Genotype & 10 & $5.74^{*}$ & $7.48^{*}$ & $14.13^{*}$ & $6.14 *$ & $8.01 *$ & $9.54 *$ & $3.70^{*}$ \\
\hline Error & 30 & 0.96 & 0.72 & 1.09 & 0.49 & 0.29 & 1.50 & 0.56 \\
\hline Mean & - & 27.89 & 28.33 & 25.75 & 27.37 & 28.64 & 25.67 & 28.45 \\
\hline $\mathrm{SA}^{1}$ & - & 0.91 & 0.95 & 0.96 & 0.96 & 0.98 & 0.92 & 0.92 \\
\hline Normality & - & 0.06 & 0.29 & 0.82 & 0.17 & 0.15 & 0.13 & 0.90 \\
\hline Homogeneity & - & 0.06 & 0.40 & 0.83 & 0.27 & 0.47 & 0.93 & 0.99 \\
\hline Additivity & - & 0.13 & 0.22 & 0.45 & 0.50 & 0.06 & 0.08 & 0.91 \\
\hline
\end{tabular}

Additivity

Fiber uniformity $(\%)$

\begin{tabular}{|l|c|c|c|c|c|c|c|c}
\hline Block & 3 & $4.43^{\text {ns }}$ & $1.97^{\text {ns }}$ & $2.53^{\text {ns }}$ & $0.24^{\text {ns }}$ & $1.32^{\text {ns }}$ & $12.94^{*}$ & $0.56^{\text {ns }}$ \\
\hline
\end{tabular}

\begin{tabular}{l|c|c|c|c|c|c|c|c|}
\hline Genotype & 10 & $9.71^{*}$ & $7.62^{*}$ & $9.22^{*}$ & $8.06^{*}$ & $6.32^{*}$ & $11.19^{*}$ & $9.31^{*}$ \\
\hline
\end{tabular}

\begin{tabular}{|l|c|c|c|c|c|c|c|c|}
\hline Error & 30 & 1.91 & 0.76 & 1.65 & 0.90 & 2.07 & 1.75 & 0.81 \\
\hline
\end{tabular}

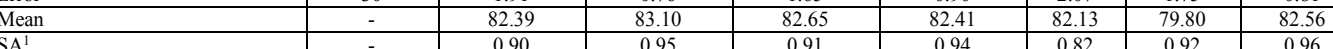

Normality

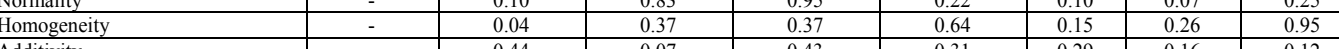

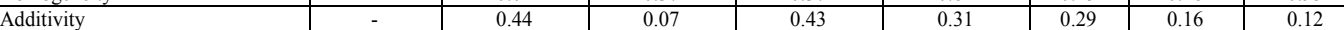

Fiber strength (gf/tex)

\begin{tabular}{|l|l|l|l|l|l|l|l|l|}
\hline Block & 3 & $5.58^{\text {ns }}$ & $7.10^{\text {ns }}$ & $2.57^{\text {ns }}$ & $11.00^{\text {ns }}$ & $1.82^{\text {ns }}$ & $1.23^{\text {ns }}$ & $1.06^{\text {ns }}$ \\
\hline
\end{tabular} \begin{tabular}{l|c|c|c|c|c|c|c|c}
\hline Genotype & 3 & $5.58^{\text {ns }}$ & $7.10^{\text {ns }}$ & $2.57^{\text {ns }}$ & $11.00^{\text {ns }}$ & $1.82^{\text {ns }}$ & $1.23^{\text {ns }}$ & $1.06^{\text {ns }}$ \\
\hline Enor & 10 & $27.19^{*}$ & $29.99^{*}$ & $33.93^{*}$ & $22.68^{*}$ & $34.25^{*}$ & $20.78^{*}$ & $45.68^{*}$ \\
\hline
\end{tabular}

\begin{tabular}{l|c|c|c|c|c|c|c|c}
\hline Error & 30 & 3.82 & 4.23 & 2.34 & 3.89 & 5.34 & 2.75 & 5.51 \\
\hline Mean & - & 27.03 & 26.99 & 24.61 & 26.57 & 28.12 & 23.10 & 27.19 \\
\hline
\end{tabular}

$\mathrm{SA}^{1}$

Normality

Homogeneity

Additivity

Fineness (micronaire)

0.93

\begin{tabular}{l|l|l|l}
0.93 & 0.93 & 0.96 \\
\hline 0.13 & 0.68 & 0.64
\end{tabular}

\begin{tabular}{|l|c|c|c|c|c|c|c|c|c|}
\hline Block & 3 & $0.07^{\text {ns }}$ & $0.31^{*}$ & $0.15^{\text {ns }}$ & $0.07^{\text {ns }}$ & $0.03^{\text {ns }}$ & $0.30^{*}$ & $0.11^{\text {ns }}$ \\
\hline Genotype & 10 & $1.15^{*}$ & $0.86^{*}$ & $1.45^{*}$ & $2.37^{*}$ & $1.55^{*}$ & $0.45^{*}$ & $1.43^{*}$ \\
\hline
\end{tabular}

\begin{tabular}{|l|c|c|c|c|c|c|c|c|c|}
\hline Error & 10 & $1.15^{*}$ & $0.86^{*}$ & $1.45^{*}$ & $2.37^{*}$ & $1.55^{*}$ & $0.45^{*}$ & $1.43^{*}$ \\
\hline
\end{tabular}

Mean

Normality

Homogeneity

Additivity

Fiber maturity (\%)

\begin{tabular}{|l|l|l|l|l|l|c|c|c|c|c|}
\hline Block & 3 & $0.52^{\mathrm{ns}}$ & $0.88^{\mathrm{ns}}$ & $0.97^{\mathrm{ns}}$ & $0.12^{\mathrm{ns}}$ & $0.87^{\mathrm{ns}}$ & $0.55^{\mathrm{ns}}$ & $0.75^{\mathrm{ns}}$ \\
\hline
\end{tabular}

\begin{tabular}{l|c|c|c|c|c|c|c|c|c|}
\hline Genotype & 10 & $6.57^{*}$ & $5.57^{*}$ & $9.27^{*}$ & $12.92^{*}$ & $11.22^{*}$ & $1.67^{*}$ & $11.74^{*}$ \\
\hline
\end{tabular}

\begin{tabular}{|l|c|c|c|c|c|c|c|c}
\hline Error & 10 & 6.57 & 5.57 & 9.27 & 12.92 & 11.22 & 1.67 \\
\hline
\end{tabular}

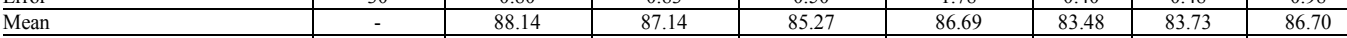

Normality

Homogeneity

\begin{tabular}{|l|c|c|c|c|c|c|c|c|}
\hline & - & 0.88 & 0.46 & 0.82 & 0.08 & 0.42 & 0.12 & 0.15 \\
\hline Additivity & - & 0.81 & 0.70 & 0.90 & 0.66 & 0.16 & 0.06 & 0.06 \\
\hline
\end{tabular}

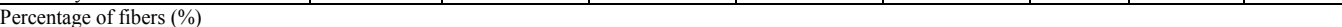

\begin{tabular}{l} 
Percentage of fibers (\%) \\
\hline Block
\end{tabular}

\begin{tabular}{l|c|c|c|c|c|c|c|c|c}
\hline Block & 3 & $1.66^{\mathrm{ns}}$ & $1.33^{\mathrm{ns}}$ & $5.54^{\mathrm{ns}}$ & $2.61^{\mathrm{ns}}$ & $4.28^{\mathrm{ns}}$ & $0.57^{\mathrm{ns}}$ & $1.13^{\mathrm{ns}}$ \\
\hline Genotype & 10 & $13.92^{*}$ & $6.91^{*}$ & $14.84^{*}$ & $21.26^{*}$ & $94.72^{*}$ & $8.83^{*}$ & $19.55^{*}$ \\
\hline
\end{tabular}

\begin{tabular}{|l|c|c|c|c|c|c|c}
\hline Error & 10 & 13.92 & 6.91 & 14.84 & 21.26 & 94.72 & 8.83 \\
\hline
\end{tabular}

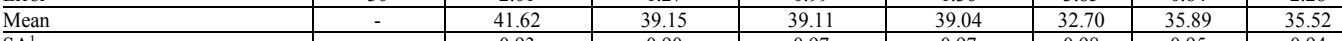

Normality

Homogeneity

Additivity

Short fiber index $(\%)$

\begin{tabular}{l|c|c|c|c|c|c|c|c|c|c|}
\hline Block & 3 & $3.81^{\text {ns }}$ & $13.48^{\text {ns }}$ & $1.85^{\text {ns }}$ & $0.14^{\text {ns }}$ & $1.38^{\text {ns }}$ & $3.65^{\text {ns }}$ & $4.20^{\text {ns }}$ \\
\hline Genotype & 10 & $13.41^{*}$ & $7.32^{\text {ns }}$ & $8.79^{*}$ & $1.57^{*}$ & $14.23^{*}$ & $14.85^{*}$ & $5.79^{*}$ \\
\hline
\end{tabular}

\begin{tabular}{|l|c|c|c|c|c|c|c|c}
\hline Genotype & 10 & $13.41^{*}$ & $7.32^{\text {ns }}$ & $8.79^{*}$ & $1.57^{*}$ & $14.23^{*}$ & $14.85^{*}$ & $5.79^{*}$ \\
\hline Error & 30 & 3.27 & 7.10 & 1.42 & 1.57 & 4.68 & 2.36 & 2.10 \\
\hline
\end{tabular}

Mean

$\mathrm{SA}^{1}$

Normality

Homogeneity

Additivity

0.87

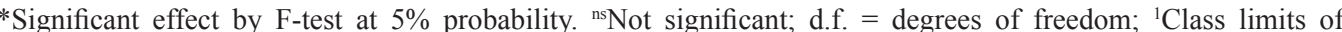
experimental accuracy established by Resende and Duarte (2007): very high (SA $\geq 0.90)$, high $(0.70 \leq \mathrm{SA}<0.90)$, moderate $(0.50 \leq \mathrm{SA}<0.70)$, and low $(\mathrm{SA}<0.50)$.

Genetics and Molecular Research 15 (3): gmr.15038557 
SA scores higher than 0.90 , which are equivalent to an $\mathrm{R}^{2}$ of $81 \%$, are typically targeted in trials because they provide very high experimental accuracy in discriminating the genotypes under evaluation (Resende and Duarte, 2007). In these seven trials with cotton genotypes, the SA ranged from 0.16 (short fiber index in trial 4) to 0.99 (fineness in trial 5 ), with a mean of 0.868 (Table 1). According to the class limits established by Resende and Duarte (2007), 41 cases showed very high experimental accuracy (SA $\geq 0.90)$, six high accuracy $(0.70 \leq \mathrm{SA}<0.90)$, and two cases low accuracy $(\mathrm{SA} \leq 0.50)$ (Table 1$)$. Therefore, we can infer that there was variability in the experimental accuracy between traits and tests but that, in general, these traits were evaluated under satisfactory experimental conditions. The variability of experimental accuracy, based on SA between traits and tests, has been verified in studies with common bean (Cargnelutti Filho and Ribeiro, 2010), soybean (Cargnelutti Filho and Gonçalves, 2011), maize (Cargnelutti Filho and Guadagnin, 2011), and irrigated rice (Cargnelutti Filho et al., 2012) genotypes.

The $r$ ranged from 0.31 (short fiber index in trials 2 and 4) to 0.89 (fineness in trial 5), with a mean of 0.65 (Table 2).

Table 2. Estimate of repeatability coefficients (r), genotypic determination coefficients $\left(\mathrm{R}^{2}\right)$, and number of measurements (repetitions) $(J)$ associated with different $R^{2}$ of seven genotypic traits of cotton genotypes, assessed in seven trials.

\begin{tabular}{|c|c|c|c|c|c|c|c|c|}
\hline Sources of variation & Trial 1 & Trial 2 & Trial 3 & Trial 4 & Trial 5 & Trial 6 & Trial 7 & Mean ${ }^{1}$ \\
\hline \multicolumn{9}{|l|}{ Fiber length (mm) } \\
\hline $\mathrm{r}$ & 0.55 & 0.70 & 0.75 & 0.74 & 0.87 & 0.57 & 0.87 & 0.72 \\
\hline $\mathrm{R}^{2}(\%)$ & 83.24 & 90.39 & 92.25 & 92.10 & 96.32 & 84.28 & 95.19 & 90.54 \\
\hline $\mathrm{J}\left(\mathrm{R}^{2}=0.80\right)$ & 3 & 2 & 1 & 1 & 1 & 3 & 1 & 2 \\
\hline $\mathrm{J}\left(\mathrm{R}^{2}=0.85\right)$ & 5 & 2 & 2 & 2 & 1 & 4 & 1 & 2 \\
\hline \multicolumn{9}{|l|}{ Fiber uniformity (\%) } \\
\hline $\mathrm{r}$ & 0.50 & 0.69 & 0.53 & 0.67 & 0.34 & 0.57 & 0.86 & 0.60 \\
\hline $\mathrm{R}^{2}(\%)$ & 80.28 & 90.07 & 82.10 & 88.88 & 67.30 & 84.37 & 94.94 & 83.99 \\
\hline $\mathrm{J}\left(\mathrm{R}^{2}=0.80\right)$ & 4 & 2 & 3 & 2 & 8 & 3 & 1 & 3 \\
\hline $\mathrm{J}\left(\mathrm{R}^{2}=0.85\right)$ & 6 & 2 & 5 & 3 & 11 & 4 & 1 & 5 \\
\hline \multicolumn{9}{|l|}{ Fiber strength (gf/tex) } \\
\hline $\mathrm{r}$ & 0.60 & 0.60 & 0.77 & 0.55 & 0.58 & 0.62 & 0.76 & 0.64 \\
\hline $\mathrm{R}^{2}(\%)$ & 85.94 & 85.89 & 93.10 & 82.86 & 84.41 & 86.74 & 90.27 & 87.03 \\
\hline $\mathrm{J}\left(\mathrm{R}^{2}=0.80\right)$ & 3 & 3 & 1 & 3 & 3 & 2 & 1 & 2 \\
\hline $\mathrm{J}\left(\mathrm{R}^{2}=0.85\right)$ & 4 & 4 & 2 & 5 & 4 & 3 & 2 & 3 \\
\hline \multicolumn{9}{|l|}{ Fineness (micronaire) } \\
\hline $\mathrm{r}$ & 0.72 & 0.29 & 0.88 & 0.80 & 0.89 & 0.57 & 0.73 & 0.70 \\
\hline $\mathrm{R}^{2}(\%)$ & 91.23 & 61.98 & 96.68 & 93.95 & 97.08 & 84.26 & 88.80 & 87.71 \\
\hline $\mathrm{J}\left(\mathrm{R}^{2}=0.80\right)$ & 2 & 10 & 1 & 1 & 1 & 3 & 2 & 3 \\
\hline $\mathrm{J}\left(\mathrm{R}^{2}=0.85\right)$ & 2 & 14 & 1 & 1 & 1 & 4 & 2 & 4 \\
\hline \multicolumn{9}{|l|}{ Fiber maturity (\%) } \\
\hline $\mathrm{r}$ & 0.64 & 0.59 & 0.81 & 0.61 & 0.87 & 0.38 & 0.85 & 0.68 \\
\hline $\mathrm{R}^{2}(\%)$ & 87.84 & 85.12 & 94.58 & 86.25 & 96.40 & 71.38 & 94.53 & 88.01 \\
\hline $\mathrm{J}\left(\mathrm{R}^{2}=0.80\right)$ & 2 & 3 & 1 & 3 & 1 & 6 & 1 & 2 \\
\hline $\mathrm{J}\left(\mathrm{R}^{2}=0.85\right)$ & 3 & 4 & 1 & 4 & 1 & 9 & 1 & 3 \\
\hline \multicolumn{9}{|c|}{ Percentage of fibers (\%) } \\
\hline $\mathrm{r}$ & 0.60 & 0.53 & 0.78 & 0.79 & 0.86 & 0.70 & 0.83 & 0.72 \\
\hline $\mathrm{R}^{2}(\%)$ & 85.57 & 81.55 & 93.35 & 93.62 & 95.93 & 90.53 & 93.51 & 90.58 \\
\hline $\mathrm{J}\left(\mathrm{R}^{2}=0.80\right)$ & 3 & 4 & 1 & 1 & 1 & 2 & 1 & 2 \\
\hline $\mathrm{J}\left(\mathrm{R}^{2}=0.85\right)$ & 4 & 5 & 2 & 2 & 1 & 2 & 1 & 2 \\
\hline \multicolumn{9}{|l|}{ Short fiber index (\%) } \\
\hline $\mathrm{r}$ & 0.44 & 0.31 & 0.57 & 0.31 & 0.34 & 0.57 & 0.70 & 0.48 \\
\hline $\mathrm{R}^{2}(\%)$ & 75.62 & 60.35 & 83.88 & 60.35 & 67.11 & 84.09 & 87.31 & 76.67 \\
\hline $\mathrm{J}\left(\mathrm{R}^{2}=0.80\right)$ & 5 & 7 & 3 & 7 & 8 & 3 & 2 & 5 \\
\hline $\mathrm{J}\left(\mathrm{R}^{2}=0.85\right)$ & 7 & 10 & 4 & 10 & 10 & 4 & 2 & 7 \\
\hline
\end{tabular}

${ }^{1}$ Mean of $\mathrm{r}\left(\mathrm{R}^{2}\right.$ and $\mathrm{J}$ associated with different $\mathrm{R}^{2}$, calculated based on mean of $\left.\mathrm{r}\right)$. 
The variability of $r$ between traits and trials is particularly important in this study by representing different real situations that enable inferences regarding $\mathrm{J}$, with overall applications. The variability of $\mathrm{r}$ and, subsequently, estimation of $\mathrm{J}$ between traits and trials were also observed in common bean (Cargnelutti Filho et al., 2009; Cargnelutti Filho and Ribeiro, 2010), soybean (Storck et al., 2009; Cargnelutti Filho and Gonçalves, 2011), maize (Cargnelutti Filho et al., 2010; Cargnelutti Filho and Guadagnin, 2011), and irrigated rice (Cargnelutti Filho et al., 2012).

The obtained $\mathrm{R}^{2}$ from four repetitions ranged from $60.35 \%$ (short fiber index in trials 2 and 4) to $97.08 \%$ (fineness in trial 5) (Table 2). For each trait, the mean $r$ from the seven trials may adequately represent the trials with cotton genotypes, and therefore, resizing the number of repetitions based on mean $r$ would be an appropriate procedure. For this reason, to achieve an $\mathrm{R}^{2}$ of $81 \%$ from means $\mathrm{r}$ of fiber length $(0.72)$, fiber uniformity $(0.60)$, fiber strength $(0.64)$, fineness $(0.70)$, fiber maturity $(0.68)$, percentage of fibers $(0.72)$, and short fiber index $(0.48)$, would require $3,3,2,2,2,2$, and 5 repetitions, respectively.

The $\mathrm{R}^{2}$ based on the mean $\mathrm{r}$ between the seven trials and for a fixed $\mathrm{J}$ of 4 , was $0.9054,0.8399,0.8703,0.8771,0.8801,0.9058$, and 0.7667 , respectively, for fiber length, fiber uniformity, fiber strength, fineness, fiber maturity, percentage of fibers, and short fiber index (Table 2). From this we may infer that four replications allow for detection of genotypic differences with a certainty of $90.54,83.99,87.03,87.71,88.01,90.58$, and $76.67 \%$ to predict the actual genotypic value for fiber length, fiber uniformity, fiber strength, fineness, fiber maturity, percentage of fibers, and short fiber index, respectively.

In general, for the seven traits, significant increases in $\mathrm{R}^{2}$ were obtained with up to four repetitions $(\mathrm{J}=4)$. For more than four repetitions, there was non-significant increases in $\mathrm{R}^{2}$, which suggests a small gain in the predictive ability to detect the actual value of the genotype. For fiber length, an important trait in cotton genetic breeding programs (Carvalho et al., 2015a,b), we found that trials with four repetitions enable identification of superior cotton genotypes with $90.54 \%$ accuracy (higher than the desired accuracy of $81 \%$ ). This level of accuracy is similar to that obtained for agronomic traits of other crops, such as common bean (Cargnelutti Filho et al., 2009), soybean (Storck et al., 2009), maize (Cargnelutti Filho et al., 2010), irrigated rice (Cargnelutti Filho et al., 2012) with 85, 80, 81, and 79\% accuracy, respectively. Therefore, it can be inferred that the selective accuracy goals of $90 \%$ have been achieved in trials with common bean, soybean, maize, irrigated rice, and cotton using a number of repetitions lower than the six theoretically recommended by Resende and Duarte (2007). However, the use of a larger number of repetitions should be encouraged in order to maximize the experimental accuracy.

\section{Conflicts of interest}

The authors declare no conflict of interest.

\section{ACKNOWLEDGMENTS}

We thank the Brazilian Federal Agency for Support and Evaluation of Graduate Education (CAPES) and the National Council for Scientific and Technological Development (CNPq) for financial support.

Genetics and Molecular Research 15 (3): gmr.15038557 


\section{REFERENCES}

Araújo WP, Pereira JR, Almeida ESAB, Araújo VL, et al. (2013). Componentes da fibra de cultivares de algodoeiro herbáceo sob lâminas de água. Rev. Ed. Agric. Sup. 28: 78-81.

Cargnelutti Filho A and Ribeiro ND (2010). Número de repetições para avaliação de caracteres de produção, fenologia e morfologia de cultivares de feijão. Cienc. Rural 40: 2446-2453. http://dx.doi.org/10.1590/S0103-84782010001200002

Cargnelutti Filho A and Gonçalves ECP (2011). Estimativa do número de repetições para a avaliação de caracteres de produtividade e de morfologia em genótipos de soja. Comun. Sci. 2: 25-33.

Cargnelutti Filho A and Guadagnin JP (2011). Planejamento experimental em milho. Rev. Cienc. Agron. 42: 1009-1016.

Cargnelutti Filho A, Ribeiro ND and Storck L (2009). Número de repetições para a comparação de cultivares de feijão. Cienc. Rural 39: 2419-2424. http://dx.doi.org/10.1590/S0103-84782009000900006

Cargnelutti Filho A, Storck L and Guadagnin JP (2010). Número de repetições para a comparação de cultivares de milho. Cienc. Rural 40: 1023-1030. http://dx.doi.org/10.1590/S0103-84782010005000073

Cargnelutti Filho A, Marchesan E, Silva LS and Toebe M (2012). Medidas de precisão experimental e número de repetições em ensaios de genótipos de arroz irrigado. Pesquisa Agropecu. Bras. 47: 336-343. http://dx.doi.org/10.1590/S0100204X2012000300004

Carvalho LP, Farias FJC and Rodrigues JIS (2015a). Selection for increased fiber length in cotton progenies from Acala and Non-Acala types. Crop Sci. 55: 985-991. http://dx.doi.org/10.2135/cropsci2014.08.0547

Carvalho LP, Farias FJC, Morello CL, Rodrigues JIS, et al. (2015b). Agronomic and technical fibers traits in elite genotypes of cotton herbaceous. Afr. J. Agric. Res. 10: 4882-4887. http://dx.doi.org/10.5897/AJAR2015.10515

Carvalho LP, Salgado CC, Farias FJC and Carneiro VQ (2015c). Estabilidade e adaptabilidade de genótipos de algodão de fibra colorida quanto aos caracteres de fibra. Cienc. Rural 45: 598-605. http://dx.doi.org/10.1590/0103$\underline{8478 \mathrm{cr} 2013023}$

Cruz CD (2006). Programa Genes: Biometria. UFV, Viçosa.

Cruz CD (2013). GENES - a software package for analysis in experimental statistics and quantitative genetics. Acta Sci. Agron. 35: 271-276. http://dx.doi.org/10.4025/actasciagron.v35i3.21251

Cruz CD and Regazzi AJ (1997). Modelos biométricos aplicados ao melhoramento genético. 2nd edn. UFV, Viçosa.

Farias FJC, Carvalho LP, Silva Filho JL and Teodoro PE (2016). Biplot analysis of phenotypic stability in upland cotton genotypes in Mato Grosso. Genet. Mol. Res. 15: doi: 10.4238/gmr.15028009.

Freitas RJ, Leandro WM and Carvalho MCS (2007). Efeito da adubação potássica via solo e foliar sobre a produção e a qualidade da fibra em algodoeiro (Gossypium hirsutum L.). Pesq. Agropec. Trop. 37: 106-112.

Jerônimo JF, Almeida FAC, Silva ORFF, Brandão ZN, et al. (2014). Qualidade da semente e fibra de algodão na caracterização do descaroçador de 25 serras. Rev. Bras. Eng. Agric. Ambient. 18: 664-671. http://dx.doi.org/10.1590/ $\underline{\mathrm{S} 1415-43662014000600015}$

Resende MDV and Duarte JB (2007). Precisão e controle de qualidade em experimentos de avaliação de cultivares. Pesq. Agropec. Trop. 37: 182-194.

Storck L, Cargnelutti Filho A, Lúcio AD and Lopes SJ (2009). Método de Papadakis e número de repetições em experimentos de soja. Cienc. Rural 39: 977-982. http://dx.doi.org/10.1590/S0103-84782009005000027.

Storck L, Garcia DC, Lopes SJ and Estefanel V (2011). Experimentação vegetal. 3rd edn. UFSM, Santa Maria.

Torres FE, Sagrilo E, Teodoro PE, Ribeiro LP, et al. (2015). Número de repetições para avaliação de caracteres em genótipos de feijão-caupi. Bragantia 74: 161-168. http://dx.doi.org/10.1590/1678-4499.0393

Genetics and Molecular Research 15 (3): gmr.15038557 